\title{
EFFECT OF SOWING SEASON ON SOYBEAN PERFORMANCE
}

\author{
EFEITO DA ÉPOCA DE SEMEADURA NO DESEMPENHO DA SOJA
}

\author{
Thúlio Pereira MATTOS'; Osvaldo Toshiyuki HAMAWAKI²; \\ Ana Paula Oliveira NOGUEIRA ${ }^{2}$; Marlize Cristina Pinheiro LUIZ ${ }^{2}$; \\ Fernanda Gabriela TEIXEIRA ${ }^{2}$; Décio SHIGIHARA ${ }^{2}$; Raphael Lemes HAMAWAKI ${ }^{3}$; \\ Cristiane Divina Lemes HAMAWAKI ${ }^{2}$.
}

1. Universidade Federal de Uberlândia, Instituto de Ciências Agrárias, Campus de Monte Carmelo, Monte Carmelo, Minas Gerais, Brasil. thuliomattos@hotmail.com; 2. Universidade Federal de Uberlândia, Instituto de Ciências Agrárias, Campus de Uberlândia, Uberlândia, MG, Brasil; 3. Southern Illinois University Carbondale, Illinois, SIU, Estados Unidos.

\begin{abstract}
The soybean presents great economic expression and high impact in the Brazilian agribusiness. The productive potential of a cultivar is expressed according to the genetic constitution and the environment. The sowing time exerts influence on the agronomic traits of the soybean, impacting the yield of grains. The objective of this study was to evaluate the influence of the sowing season on the productive potential and the agronomic traits of soybean. The work was conducted at the Capim Branco experimental farm, belonging to the Federal University of Uberlândia. Twelve cultivars (UFUS 6901, UFUS 7415, BRSMG 68, TMG 801, TMG 7062 IPRO, TMG 2158 IPRO, BRS 7270 IPRO, NA 5909 RR, NS 6909 RR, CD 2737 RR, P98Y30 RR e BRASMAX Desafio RR) and four sowing seasons (October 22, November 5, December 22, 2016 and January 5, 2017) were used. The experimental design was a randomized block design with four replicates. The evaluated characters were: number of days for flowering and maturity, plant height at maturity, insertion height for the first pod, number of nodes at maturity, total number of pods, number of tainted pods and productivity. The sowing carried out in October and November contributed to obtain a larger number of nodes and a greater height of plants at maturity, which are agronomic traits favorable to higher productivity. Sowing delay seriously affected soybean yield and in the Uberlândia MG region the ideal sowing time was October 22, before the beginning of November. In the late sowing in December and January, the cultivars that had their productions less affected were the conventional cultivars BRSMG 68 and TMG 801.
\end{abstract}

KEYWORDS: Glycine max. Cultural management. Predictability.

\section{INTRODUCTION}

In order for the soybean crop to show good growth, development and maximum productive potential, it is imperative that the soil has good physical characteristics and correction of the chemical part. In addition to soil, temperature, humidity, photoperiod, ideal sowing season, cultivation site and adequate management techniques are fundamental for the soybean to express high productivity (SILVA; SEDIYAMA; BORÉM, 2015).

In soybean cultivation, when sowing is done outside the recommended season in a region, a reduction in plant height is promoted, grain productivity is impaired and the composition and physiological quality of the seeds are affected (EMBRAPA, 2011).

The place where the sowing is performed is of great importance, because the soybean is a plant sensitive to the photoperiod and the amount of hours during the day is determined according to the latitude (SEDIYAMA; TEIXEIRA; BARROS,
2009). Late sowing causes a reduction of the cycle and affects the amount of radiation captured (MEOTTI et al., 2012).

Losses in the range of 30 to $50 \%$ in productivity can occur in late sowing and when soybean sowing is carried out in the off-season, losses can reach $70 \%$, compared to the ideal sowing season (CÂMARA; HEIFFIG, 2000). Each region should have its sowing season constantly evaluated for updating, since new cultivars are constantly available for cultivation in different regions (SILVA; SEDIYAMA; BORÉM, 2015).

The sowing season has an impact on the production of soybeans, acting directly on the yield and quality of seeds and grains. With delay of sowing, productivity is affected (BALENA et al., 2016). It is essential to carry out studies on the sowing season for each site and regional studies, due to the variability in the environmental conditions (AMORIM et al., 2011; MEOTTI et al., 2012).

In each cultivation region, suitable soybean cultivars should be used for each site and sowing 
should be done at the recommendation time, combining the other cultural management techniques in the crop, in order to achieve high productivity (SILVA; SEDIYAMA; BORÉM, 2015).

Studies performed by Amorim et al. (2011) in Uberlândia/MG, using seven soybean cultivars at four sowing dates, performed on October 30, November 15, December 14 and December 31, concluded that the delay of sowing influenced the architecture and behavior of plants, promoted reduction in plant height and number of days for flowering, interfering with yield and grain productivity.

Balena et al. (2016), in order to evaluate the influence of the sowing time on soybean in three sowing dates (October 22, November 17 and December 11) in the municipality of Xanxerê/SC, verified a reduction in the cycle and yield of with the delay of sowing.
The objective of this study was to evaluate the influence of different sowing times on the agronomic performance of soybean cultivars in the Uberlândia-MG region.

\section{MATERIALS AND METHODS}

The experiment was carried out in the 2016/2017 harvest, at the Fazenda Capim Branco experimental station $\left(18^{\circ} 52\right.$ '50.63 "S and $48^{\circ} 20^{\prime}$ $32.07 \mathrm{"} \mathrm{W}$ and $805 \mathrm{~m}$ altitude), belonging to the Federal University of Uberlândia (UFU), in the municipality of Uberlândia, Minas Gerais.

The region is of type Aw climate, according to the classification of Köppen (1948), rainy summer (October to March) and humid tropical climate with dry season during the winter (April to September). The meteorological data, precipitation and temperature during the conduction of the experiment are represented in Figure 1.

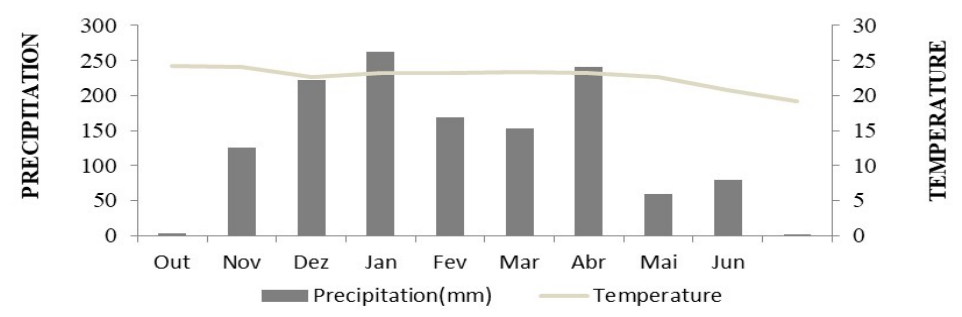

Figure 1. Average temperature and precipitation in the months of October/2016 to June/ 2017 in Uberlândia, MG. Source: Laboratory of Climatology and Environmental Meteorology.

Seeding was carried out in four seasons: October 22, November 5, December 22, 2016, and January 5, 2017. A randomized complete block design was used, with four replications, in factorial scheme 12 (cultivars) x 4 (season). The cultivars used to conduct the test were: UFUS 6901 (early and indeterminate growth), UFUS 7415 (early and semideterminate growth), cultivars of semi-early and determinate growth: BRSMG 68, TMG 801 and P98Y30 RR, BRASMAX Desafio RR (semi-early and indeterminate growth), TMG 7062 IPRO (super-early and semideterminate growth), and cultivars super-early and indeterminate growth: TMG 2158 IPRO, BRS 7270 IPRO, NA 5909 RR, NS 6909 RR, CD 2737 RR.

The experiment was conducted in an area with Dystrophic Dark Red Latosol, with a clayey texture. The soil was prepared in a conventional manner, with a plowing and two harrowing before sowing, the fertilization was done according to the need of the soybean crop and the soil analysis, in the amount of $400 \mathrm{~kg} \mathrm{ha}^{-1}$ of the formulated 02-28-18.
The seeds were treated with fungicide Carbendazim and Tiram, followed by inoculation with Bradyrizobium japonicum and manual seeding.

The plant populations used according to the breeders' recommendation were as follows: 240,000 plants ha ${ }^{-1}$ for cultivar P98Y30 RR; 260,000 plants $\mathrm{ha}^{-1}$ for UFUS 6901, UFUS 7415, BRSMG 68 and TMG 801; 320,000 plants ha ${ }^{-1}$ for CD 2737 RR and NS 6909 RR; 360,000 plants ha ${ }^{-1}$ for TMG 7062 IPRO, TMG 2158 IPRO, BRS 7270 IPRO and BMX Desafio RR; and 400,000 plants ha ${ }^{-1}$ for NA 5909 RR. Sowing was performed by placing $30 \%$ more seeds and performing the thinning in V1 stage to establish the desired population.

After sowing weed control was carried out with pre-emergence herbicide S-Metolachlor and Cletodim, 25 days after the emergence of soybean seedlings. The control followed with manual meadows until the end of the crop cycle in each of the four sowing seasons.

At 30 days after emergence, cobalt and molybdenum, important in the biological fixation of nitrogen, were applied. Three applications of foliar fertilizer were carried out, the first one in the 
flowering and two biweekly applications, with the following composition: $6.5 \%$ of nitrogen $(\mathrm{N}), 8 \%$ of phosphorus (P2O5), $8 \%$ of potassium (K2O), 1 $\%$ of calcium $(\mathrm{Ca}), 0.5 \%$ of magnesium $(\mathrm{Mg}), 0.6$ $\%$ of boron (B), $0.5 \%$ manganese (Mn) and $1 \%$ zinc $(\mathrm{Zn})$ at the dosage of $1 \mathrm{~L} \mathrm{ha}^{-1}$.

The control of Phakopsora pachyrhizi and pests was carried out according to the needs of the crop (EMBRAPA, 2013). For the control of diseases was used the products with active principle of azoxystrobin, mancozeb, trifloxystrobin, prothioconazole, epoxiconazole and fluxapiroxade. The caterpillar, bug and other insect complex were controlled with acetamiprid, thiamethoxam, acephate, alpha-cypermethrin and lambdacyhalothrin.

Within the useful plot, 5 random plants were sampled, which were identified and used in the evaluation at the reproductive stage; the stages were determined by the (FEHR; CAVINESS, 1977). The following characters were evaluated:

a) Number of days for flowering (NDF) and maturity (NDM): it was considered from the emergency day up to $50 \%$ of the useful part to present at least 1 open flower (R1) and when $95 \%$ of the pods in the useful part presented mature staining (R8);

b) Height of the plant at maturity (HPM): Measuring the distance between the ground surface and the end of the main rod, in stage R8, using a ruler graduated in centimeters.

c) Height of insertion of the first pod (HFP): distance in centimeters between the soil surface until insertion of the first pod.

d) Number of nodes in maturity (NNM): Count the number of nodes of the main stem in the stage R8.

e) Number of pods (NP): obtained by the total number of pods of the 5 plants sampled within the useful plot.

f) Number of tainted pods (NTP): obtained by the total number of tainted pods of the 5 plants sampled within the useful plot.

g) Grain productivity (PROD): obtained by means of the harvest of each useful plot, carrying out the tracing and weighing of the grains, estimating the grain productivity per hectare $\left(\mathrm{kg} \mathrm{ha}^{-}\right.$ ${ }^{1}$ ), with correction to $13 \%$ of humidity according to the equation below:

$F W=I W \times \frac{(100-I M)}{(100-F M)}$

In which:

FW: Final weight of the corrected sample;

IW: Initial weight of the sample;

IM: Initial moisture of the sample;
FM: Final moisture of the sample (13\%).

To test the differences between treatments, the analysis of variance was performed. The averages of the significant variables were grouped by the Scott Knott test for the qualitative factor, at 5 $\%$ of significance, using the statistical program Genes (CRUZ, 2016).

\section{RESULTS AND DISCUSSION}

In order to evaluate the effects of sowing seasons, the analysis of joint variance was performed (Table 1).

It was adopted the adjustments of degree of freedom of residues when the ratio between the largest and smallest mean square of the residue was higher than 7, according to the limit suggested by Ramalho et al. (2012).

Significant effects were observed for cultivars, sowing season and interaction between both factors (Table 1). The occurrence of the interaction cultivar by sowing season ( $\mathrm{C} \times \mathrm{SS}$ ), shows the differential behavior of the cultivars in relation to the phenotypes regarding of the environmental oscillations.

In studies carried out by Cruz et al. (2010), the occurrence of highly significant (C $\mathrm{x}$ SS) interaction $(\mathrm{P}<0.01)$, according to the $\mathrm{F}$ test, was detected for the number of tainted pods (NTP) and grain productivity (PROD).

According to Nogueira et al. (2013), the vegetative cycle is an important character in soybean, because it is during this period that the plant grows and accumulates leaves that reflect in the dry matter, important for obtaining high productivity. The soybean has its growth comprised in two phases, the vegetative and the reproductive, whose duration is influenced by the environmental conditions. The number of days for flowering and maturity provide the time of development of the plant in the vegetative and reproductive stages.

The cultivars UFUS 7415, BRSMG 68, TMG 801 and P98Y30, sown in the months of October and November, presented higher NDF in relation to the last two seasons (Table 2), evidencing in these cultivars a tendency in the reduction of NDF as the sowing delayed.

It was evidenced that for the earlier cultivars TMG 7062 IPRO, TMG 2158 IPRO, BRS 7270 IPRO, NA 5909 RR and CD 2737 RR, sowing in January provided a longer vegetative period (Table 2 ). Therefore, in most of the cultivars did not occur the anticipation of flowering with delayed sowing. 
Table 1. Brief analysis of combined variance of agronomic traits and grain productivity of 12 soybean cultivars at four sowing seasons

\begin{tabular}{|c|c|c|c|c|c|}
\hline \multirow{2}{*}{$\mathrm{FV}$} & \multirow{2}{*}{ GL } & \multicolumn{4}{|c|}{ Medium Squares } \\
\hline & & NDF & NDM & HPM & HFP \\
\hline Blocks/ Sowing season & 12 & 0.45 & 0.64 & 87.40 & 5.14 \\
\hline Cultivars & 11 & $569.59 * *$ & $1603.84 * *$ & $917.25 * *$ & $29.71 * *$ \\
\hline Sowing season & 3 & $138.86^{* *}$ & $286.35^{* *}$ & $15451.36^{* *}$ & $119.69^{* *}$ \\
\hline Cultivars x Sowing season & 33 & $20.80^{* *}$ & $23.50 * *$ & $86.07^{* *}$ & $24.61 * *$ \\
\hline Error & 132 & 0.46 & 0.64 & 39.79 & 5.38 \\
\hline$>\mathrm{QMR} /<\mathrm{QMR}$ & & 2.40 & 2.63 & 2.28 & 1.37 \\
\hline \multirow{2}{*}{ FV } & \multirow{2}{*}{ GL } & \multicolumn{4}{|c|}{ Medium Squares } \\
\hline & & NNM & NP & NTP & PROD \\
\hline Blocks/ Sowing season & 12 & 0.76 & 78.23 & 4.27 & 323198.71 \\
\hline Cultivars & 11 & $19.20^{* *}$ & $332.61 * *$ & $15.80^{\mathrm{ns}}$ & $709810.35^{* *}$ \\
\hline Sowing season & 3 & $161.45^{* *}$ & $23150.10 * *$ & $211.82 * *$ & $203400983.59^{* *}$ \\
\hline Cultivars $\mathrm{x}$ Sowing season & 33 & $4.08 * *$ & $570.90 * *$ & $21.33 * *$ & $1413709.11^{* *}$ \\
\hline Error & 137 & 0.88 & 124.82 & 8.35 & 200957.80 \\
\hline$>\mathrm{QMR} /<\mathrm{QMR}$ & & 1.83 & 10.35 & 59.57 & 28.10 \\
\hline
\end{tabular}

Table 2. Averages of the number of days for flowering evaluated in twelve soybean cultivars at four sowing seasons in the municipality of Uberlândia, MG, in the agricultural year of 2016/2017.

\begin{tabular}{lccccc}
\cline { 2 - 6 } CULTIVARS & \multicolumn{5}{c}{ SOWING SEASONS } \\
\cline { 2 - 6 } & $\mathbf{2 2 / 1 0 / 2 0 1 6}$ & $\mathbf{0 5 / 1 1 / 2 0 1 6}$ & $\mathbf{2 2 / 1 2 / 2 0 1 6}$ & $\mathbf{0 5 / 0 1 / 2 0 1 7}$ & Averages \\
\hline UFUS 6901 & $37.25 \mathrm{Bd}$ & $38.50 \mathrm{Ad}$ & $35.25 \mathrm{Cd}$ & $37.00 \mathrm{Bd}$ & 37.00 \\
UFUS 7415 & $43.00 \mathrm{Ac}$ & $42.00 \mathrm{Bc}$ & $40.00 \mathrm{Cc}$ & $40.25 \mathrm{Cc}$ & 41.31 \\
BRSMG 68 & $46.50 \mathrm{Bb}$ & $50.00 \mathrm{Aa}$ & $42.50 \mathrm{Cb}$ & $39.75 \mathrm{Dc}$ & 44.69 \\
TMG 801 & $48.25 \mathrm{Ba}$ & $50.50 \mathrm{Aa}$ & $46.00 \mathrm{Ca}$ & $46.25 \mathrm{Ca}$ & 47.75 \\
TMG 7062 IPRO & $36.25 \mathrm{Be}$ & $38.50 \mathrm{Ad}$ & $31.75 \mathrm{Ce}$ & $37.75 \mathrm{Ad}$ & 36.06 \\
TMG 2158 IPRO & $31.00 \mathrm{Cg}$ & $32.00 \mathrm{Bf}$ & $29.00 \mathrm{Dg}$ & $33.25 \mathrm{Af}$ & 31.31 \\
BRS 7270 IPRO & $30.75 \mathrm{Cg}$ & $32.00 \mathrm{Bf}$ & $30.00 \mathrm{Cf}$ & $34.25 \mathrm{Ae}$ & 31.75 \\
NA 5909 RR & $29.75 \mathrm{Ch}$ & $32.00 \mathrm{Bf}$ & $29.25 \mathrm{Cg}$ & $34.75 \mathrm{Ae}$ & 31.44 \\
NS 6909 RR & $36.00 \mathrm{Ce}$ & $39.00 \mathrm{Ad}$ & $30.50 \mathrm{Df}$ & $37.25 \mathrm{Bd}$ & 35.69 \\
CD 2737 RR & $30.00 \mathrm{Ch}$ & $32.25 \mathrm{Bf}$ & $30.25 \mathrm{Cf}$ & $36.75 \mathrm{Ad}$ & 32.31 \\
P98Y30 RR & $47.00 \mathrm{Bb}$ & $48.00 \mathrm{Ab}$ & $45.75 \mathrm{Ca}$ & $41.00 \mathrm{Db}$ & 45.44 \\
BMX Desafio RR & $32.00 \mathrm{Cf}$ & $34.25 \mathrm{Be}$ & $30.25 \mathrm{Df}$ & $37.00 \mathrm{Ad}$ & 33.38 \\
\hline Averages & 37.31 & 39.08 & 35.04 & 37.93 & \\
CV (\%) & 1.82 & & & \\
\hline Averages followed by the same capital letter on the line and lowercase in the column, do not differ by Scott Knott's test at 5\% \\
probability. CV: coefficient of variation. NDF: number of days for flowering.
\end{tabular}


Soybean cultivars differ in their sensitivity to photoperiod (FARIAS; NEPOMUCENO; NEUMAIER, 2007). Exposure of plants to short photoperiods may favor early flowering. However, it occurs that cultivars of the central Brazilian region have a long juvenile period, so during the juvenile phase the soybean is not induced to the early flowering, even when submitted to a very short inductive photoperiod, thus allowing a greater vegetative growth (SEDIYAMA, 2009).

Kumagai and Sameshima (2014), evaluating the influence of temperature increase on soybean production, stated that early cultivars are less sensitive to variations in the photoperiod compared to late cultivars, which are more sensitive. In the present study, early flowering was not verified as the sowing delayed for most of the cultivars.

In relation to the number of days to maturity, the cultivars that presented the highest precocity were the UFUS 6901, TMG 7062 IPRO, TMG 2158 IPRO, BRS 7270 IPRO, NA 5909 RR and NS 6909 RR, even with variation in the sowing season, their cycles were smaller, an expected result, since they present greater precocity (Table 3). As sowing delayed, there was no gradual decrease in NDM or in the cultivar cycle.

Balena et al. (2016), in Xanxerê - Santa Catarina, evaluating three sowing times, observed that the phenological cycle of the plants was smaller with the delay of sowing.

Table 3. Averages of the number of days of maturity evaluated in twelve soybean cultivars at four sowing seasons in the municipality of Uberlândia, MG, in the agricultural year of 2016/2017.

NDM

\begin{tabular}{lccccc}
\cline { 2 - 5 } CULTIVARS & \multicolumn{5}{c}{ SOWING SEASONS } \\
\cline { 2 - 6 } & $\mathbf{2 2 / 1 0 / 2 0 1 6}$ & $\mathbf{0 5 / 1 1 / 2 0 1 6}$ & $\mathbf{2 2 / 1 2 / 2 0 1 6}$ & $\mathbf{0 5 / 0 1 / 2 0 1 7}$ & Averages \\
\hline UFUS 6901 & $102.25 \mathrm{Bg}$ & $102.50 \mathrm{Bf}$ & $105.75 \mathrm{Ag}$ & $102.75 \mathrm{Bf}$ & 103.31 \\
UFUS 7415 & $112.75 \mathrm{Be}$ & $110.00 \mathrm{Ce}$ & $114.00 \mathrm{Af}$ & $111.00 \mathrm{Cd}$ & 111.94 \\
BRSMG 68 & $122.50 \mathrm{Ac}$ & $120.00 \mathrm{Bc}$ & $122.75 \mathrm{Ac}$ & $118.75 \mathrm{Cb}$ & 121.00 \\
TMG 801 & $124.75 \mathrm{Ab}$ & $122.50 \mathrm{Bb}$ & $124.00 \mathrm{Ab}$ & $121.25 \mathrm{Ca}$ & 123.13 \\
TMG 7062 IPRO & $101.25 \mathrm{Bg}$ & $102.50 \mathrm{Bf}$ & $105.00 \mathrm{Ag}$ & $101.75 \mathrm{Bf}$ & 102.63 \\
TMG 2158 IPRO & $96.00 \mathrm{Ci}$ & $95.25 \mathrm{Ch}$ & $105.00 \mathrm{Ag}$ & $99.25 \mathrm{Bh}$ & 98.88 \\
BRS 7270 IPRO & $95.50 \mathrm{Ci}$ & $95.75 \mathrm{Ch}$ & $103.75 \mathrm{Ah}$ & $100.25 \mathrm{Bg}$ & 98.81 \\
NA 5909 RR & $95.75 \mathrm{Ci}$ & $96.50 \mathrm{Ch}$ & $103.75 \mathrm{Ah}$ & $98.75 \mathrm{Bh}$ & 98.69 \\
NS 6909 RR & $99.50 \mathrm{Dh}$ & $101.25 \mathrm{Cg}$ & $109.50 \mathrm{Af}$ & $105.00 \mathrm{Be}$ & 104.81 \\
CD 2737 RR & $107.75 \mathrm{Df}$ & $110.00 \mathrm{Ce}$ & $115.75 \mathrm{Ae}$ & $111.25 \mathrm{Bd}$ & 111.19 \\
P98Y30 RR & $128.50 \mathrm{Aa}$ & $125.75 \mathrm{Ba}$ & $129.00 \mathrm{Aa}$ & $120.25 \mathrm{Ca}$ & 125.88 \\
BMX Desafio RR & $119.50 \mathrm{Ad}$ & $116.25 \mathrm{Bd}$ & $118.75 \mathrm{Ad}$ & $113.75 \mathrm{Cc}$ & 117.06 \\
\hline Averages & 108.83 & 108.19 & 113.42 & 108.67 & \\
CV (\%) & 0.73 & & & \\
\hline Averages followed by the same capital letter on the line and lowercase in the column, do not differ by Scott Knott's test at 5\% \\
probability. CV: coefficient of variation. NDM: number of days of maturity.
\end{tabular}

The height of the plants is an important character for the soybean, since it impacts on the mechanized harvest and the productive potential of the crop. According to Sediyama et al. (2015), the ideal height is between 50 and $90 \mathrm{~cm}$, very low or high plants favor grain losses in the mechanized harvesting process or may have a low productivity potential. Table 4 shows that the plant height of the cultivars between the sowing dates of October and November were predominantly similar, whereas for sowing in December and January a reduction to 50 $\%$ of the height of the cultivars was observed. In general, there was no reduction in plant height at sowing in the months of October and November, at October ranged from 62 to $100 \mathrm{~cm}$ and at November from 59 to $91 \mathrm{~cm}$, the cultivars presented mostly at those times according to the recommended standard for commercial cultivars.

The present study demonstrates that occurred the height reduction of plants with delayed sowing, later sowings result in smaller plants, comparing with the recommended season.

The height of insertion of the first pod is genetically defined; however, they may be influenced by several factors, such as sowing time, population density, line spacing, water supply, soil 
fertility and air temperature (GUIMARÃES et al., 2008).

Tabela 4. Averages height of plants at maturity evaluated in twelve soybean cultivars at four sowing seasons in the municipality of Uberlândia, MG, in the agricultural year of 2016/2017.

\section{HPM}

\begin{tabular}{lccccc}
\cline { 2 - 5 } CULTIVARS & \multicolumn{5}{c}{ SOWING SEASONS } \\
\cline { 2 - 6 } & $\mathbf{2 2 / 1 0 / 2 0 1 6}$ & $\mathbf{0 5 / 1 1 / 2 0 1 6}$ & $\mathbf{2 2 / 1 2 / 2 0 1 6}$ & $\mathbf{0 5 / 0 1 / 2 0 1 7}$ & Averages \\
\hline UFUS 6901 & $98.00 \mathrm{Aa}$ & $90.55 \mathrm{Aa}$ & $58.90 \mathrm{Ba}$ & $49.06 \mathrm{Ca}$ & 74.13 \\
UFUS 7415 & $79.65 \mathrm{Ac}$ & $76.20 \mathrm{Ab}$ & $55.75 \mathrm{Ba}$ & $47.05 \mathrm{Ba}$ & 64.66 \\
BRSMG 68 & $100.00 \mathrm{Aa}$ & $91.10 \mathrm{Aa}$ & $64.27 \mathrm{Ba}$ & $46.15 \mathrm{Ca}$ & 75.38 \\
TMG 801 & $77.10 \mathrm{Ac}$ & $77.30 \mathrm{Ab}$ & $54.50 \mathrm{Ba}$ & $40.15 \mathrm{Cb}$ & 62.26 \\
TMG 7062 IPRO & $77.15 \mathrm{Ac}$ & $67.26 \mathrm{Bc}$ & $46.80 \mathrm{Cb}$ & $38.95 \mathrm{Cb}$ & 57.54 \\
TMG 2158 IPRO & $66.25 \mathrm{Ad}$ & $59.05 \mathrm{Ac}$ & $48.85 \mathrm{Bb}$ & $34.80 \mathrm{Cb}$ & 52.24 \\
BRS 7270 IPRO & $73.85 \mathrm{Ac}$ & $65.95 \mathrm{Ac}$ & $44.00 \mathrm{Bb}$ & $40.95 \mathrm{Bb}$ & 56.19 \\
NA 5909 RR & $62.85 \mathrm{Ad}$ & $69.50 \mathrm{Ac}$ & $44.55 \mathrm{Bb}$ & $36.70 \mathrm{Bb}$ & 53.40 \\
NS 6909 RR & $76.60 \mathrm{Ac}$ & $80.90 \mathrm{Ab}$ & $47.86 \mathrm{Bb}$ & $43.00 \mathrm{Ba}$ & 62.09 \\
CD 2737 RR & $84.25 \mathrm{Ab}$ & $87.73 \mathrm{Aa}$ & $57.85 \mathrm{Ba}$ & $47.75 \mathrm{Ca}$ & 69.40 \\
P98Y30 RR & $86.06 \mathrm{Ab}$ & $80.75 \mathrm{Ab}$ & $58.05 \mathrm{Ba}$ & $44.40 \mathrm{Ca}$ & 67.32 \\
BMX Desafio RR & $76.35 \mathrm{Ac}$ & $68.75 \mathrm{Ac}$ & $49.85 \mathrm{Bb}$ & $47.55 \mathrm{Ba}$ & 60.63 \\
\hline Averages & 79.84 & 76.25 & 52.60 & 43.04 & \\
CV (\%) & 10.02 & & & & \\
\hline A & & & &
\end{tabular}

Averages followed by the same capital letter on the line and lowercase in the column, do not differ by Scott Knott's test at $5 \%$ probability. CV: coefficient of variation. HPM: plant height at maturity.

The insertion of the first pod is an important characteristic for mechanized harvesting because, in order to avoid loss of harvesting by the cutting bar, the minimum height of the first pod should be 10 to $15 \mathrm{~cm}$ (SEDIYAMA et al., 2015).

The cultivars TMG 7062 IPRO, BRS 7270 IPRO, NS 6909 RR, CD 2737 RR and BMX DESAFIO RR showed no difference in HFP in relation to the different sowing seasons (Table 5).

The cultivars BRSMG 68, TMG 801 and P98Y30 RR presented higher HFP in the sowings of October and November in relation to the sowing of December and January. The delay of sowing influenced the decrease of HFP. The cultivars UFUS 6901, UFUS 7415, TMG 2158 IPRO and NA 5909 RR showed no reduction of HFP with delay of sowing. In the present work, a reduction of the HFP was observed, comparing the sowing in the recommended season with the off-season, only in cultivars BRSMG 68, TMG 801 and P98Y30 RR. This fact occurred in a study by Ludwig et al. (2010), who evaluated two sowing seasons, November 10 and January 3, and observed that the average HFP was $21 \mathrm{~cm}$ at the first sowing and 10 $\mathrm{cm}$ at the second.
Studies have shown that NNM is a character correlated with grain productivity (NOGUEIRA et al., 2012). It is expected that a soybean plant with high productive potential will have 17 to 18 knots in the main stem (SEDIYAMA et al., 2015). In this study it was noticed that the sowing of December and January favored a reduction in NNM (Table 6).

It was verified that the delay of sowing influenced the decrease of the NNM, comparing the sowings of October and November with the last two to $50 \%$ of the cultivars. The cultivars UFUS 6901 , TMG 7062 IPRO, TMG 2158 IPRO, P98Y30 RR and BMX Desafio RR showed higher an average of the NNM only in the first sowing, in the BRSMG 68 cultivar there was no reduction of the characteristic as the sowing delayed (Table 6).

In a study by Ludwig et al. (2010) aiming to identify influence of two sowing seasons, the first in November, the recommended season for the region and the other in January; and soybean densities in Jari, Rio Grande do Sul, also verified a higher number of nodes in the main stem in the first sowing season. 
Table 5. Averages of the height of the first pod insertion evaluated in twelve soybean cultivars at four sowing seasons in the municipality of Uberlândia, MG, in the agricultural year of 2016/2017.

\begin{tabular}{lccccc}
\hline & \multicolumn{5}{c}{ HFP } \\
\cline { 2 - 5 } CULTIVARS & $\mathbf{5}$ & \multicolumn{3}{c}{ SOWING SEASONS } \\
\cline { 2 - 5 } & $\mathbf{2 2 / 1 0 / 2 0 1 6}$ & $\mathbf{0 5 / 1 1 / 2 0 1 6}$ & $\mathbf{2 2 / 1 2 / 2 0 1 6}$ & $\mathbf{0 5 / 0 1 / 2 0 1 7}$ & Averages \\
\hline UFUS 6901 & $19.20 \mathrm{Aa}$ & $16.30 \mathrm{Ab}$ & $10.00 \mathrm{Bb}$ & $17.80 \mathrm{Aa}$ & 15.83 \\
UFUS 7415 & $15.80 \mathrm{Bb}$ & $19.50 \mathrm{Aa}$ & $9.60 \mathrm{Db}$ & $13.20 \mathrm{Cb}$ & 14.53 \\
BRSMG 68 & $21.65 \mathrm{Aa}$ & $19.75 \mathrm{Aa}$ & $9.40 \mathrm{Cb}$ & $15.85 \mathrm{Ba}$ & 16.66 \\
TMG 801 & $16.00 \mathrm{Ab}$ & $15.90 \mathrm{Ab}$ & $10.25 \mathrm{Bb}$ & $11.25 \mathrm{Bb}$ & 13.35 \\
TMG 7062 IPRO & $12.80 \mathrm{Ac}$ & $14.80 \mathrm{Ac}$ & $11.75 \mathrm{Aa}$ & $14.00 \mathrm{Ab}$ & 13.34 \\
TMG 2158 IPRO & $11.30 \mathrm{Bc}$ & $14.05 \mathrm{Ac}$ & $16.25 \mathrm{Aa}$ & $12.55 \mathrm{Bb}$ & 13.54 \\
BRS 7270 IPRO & $11.30 \mathrm{Ac}$ & $10.80 \mathrm{Ac}$ & $12.73 \mathrm{Aa}$ & $12.20 \mathrm{Ab}$ & 11.76 \\
NA 5909 RR & $12.10 \mathrm{Bc}$ & $16.65 \mathrm{Ab}$ & $13.80 \mathrm{Ba}$ & $13.50 \mathrm{Bb}$ & 14.01 \\
NS 6909 RR & $11.50 \mathrm{Ac}$ & $13.45 \mathrm{Ac}$ & $13.13 \mathrm{Aa}$ & $12.05 \mathrm{Ab}$ & 12.53 \\
CD 2737 RR & $11.55 \mathrm{Ac}$ & $14.66 \mathrm{Ac}$ & $13.00 \mathrm{Aa}$ & $11.60 \mathrm{Ab}$ & 12.70 \\
P98Y30 RR & $16.00 \mathrm{Ab}$ & $17.10 \mathrm{Ab}$ & $9.80 \mathrm{Bb}$ & $12.60 \mathrm{Bb}$ & 13.88 \\
BMX Desafio RR & $14.25 \mathrm{Ac}$ & $13.70 \mathrm{Ac}$ & $12.65 \mathrm{Aa}$ & $13.35 \mathrm{Ab}$ & 13.49 \\
\hline Averages & 14.45 & 15.56 & 11.86 & 13.33 & \\
CV (\%) & 16.81 & & & \\
\hline Averages followed by the same capital letter on the line and lowercase in the column, do not differ by Scott Knott's test at 5\% \\
probability. CV: coefficient of variation. HFP: height of the first pod insertion.
\end{tabular}

Table 6. Averages number of nodes at maturity evaluated in twelve soybean cultivars at four sowing seasons in the municipality of Uberlândia, MG, in the agricultural year of 2016/2017.

\begin{tabular}{lccccc}
\hline & \multicolumn{5}{c}{ NNM } \\
\cline { 2 - 6 } CULTIV ARS & $\mathbf{5}$ & \multicolumn{3}{c}{ SOWING SEASONS } \\
\cline { 2 - 6 } & $\mathbf{2 2 / 1 0 / 2 0 1 6}$ & $\mathbf{0 5 / 1 1 / 2 0 1 6}$ & $\mathbf{2 2 / 1 2 / 2 0 1 6}$ & $\mathbf{0 5 / 0 1 / 2 0 1 7}$ & Averages \\
\hline UFUS 6901 & $18.55 \mathrm{Aa}$ & $15.05 \mathrm{Bb}$ & $15.65 \mathrm{Ba}$ & $13.26 \mathrm{Ca}$ & 15.63 \\
UFUS 7415 & $14.25 \mathrm{Ac}$ & $14.35 \mathrm{Ac}$ & $11.50 \mathrm{Bc}$ & $10.70 \mathrm{Bb}$ & 12.70 \\
BRSMG 68 & $13.90 \mathrm{Bc}$ & $15.15 \mathrm{Ab}$ & $13.75 \mathrm{Ba}$ & $11.30 \mathrm{Cb}$ & 13.53 \\
TMG 801 & $14.80 \mathrm{Ac}$ & $15.25 \mathrm{Ab}$ & $13.05 \mathrm{Bb}$ & $12.85 \mathrm{Ba}$ & 13.99 \\
TMG 7062 IPRO & $18.15 \mathrm{Aa}$ & $15.20 \mathrm{Bb}$ & $14.95 \mathrm{Ba}$ & $11.50 \mathrm{Cb}$ & 14.95 \\
TMG 2158 IPRO & $15.15 \mathrm{Ac}$ & $13.05 \mathrm{Bc}$ & $12.45 \mathrm{Bb}$ & $11.62 \mathrm{Bb}$ & 13.07 \\
BRS 7270 IPRO & $16.25 \mathrm{Ab}$ & $16.70 \mathrm{Aa}$ & $11.53 \mathrm{Cc}$ & $14.00 \mathrm{Ba}$ & 14.62 \\
NA 5909 RR & $14.05 \mathrm{Ac}$ & $13.50 \mathrm{Ac}$ & $11.35 \mathrm{Bc}$ & $10.40 \mathrm{Bb}$ & 12.33 \\
NS 6909 RR & $16.15 \mathrm{Ab}$ & $15.45 \mathrm{Ab}$ & $11.60 \mathrm{Bc}$ & $12.15 \mathrm{Ba}$ & 13.84 \\
CD 2737 RR & $18.20 \mathrm{Aa}$ & $17.00 \mathrm{Aa}$ & $14.35 \mathrm{Ba}$ & $12.55 \mathrm{Ca}$ & 15.53 \\
P98Y30 RR & $17.46 \mathrm{Aa}$ & $15.85 \mathrm{Bb}$ & $14.95 \mathrm{Ba}$ & $12.50 \mathrm{Ca}$ & 15.19 \\
BMX Desafio RR & $17.00 \mathrm{Ab}$ & $14.50 \mathrm{Bc}$ & $14.45 \mathrm{Ba}$ & $11.65 \mathrm{Cb}$ & 14.40 \\
\hline Averages & 16.16 & 15.09 & 13.30 & 12.04 & \\
CV (\%) & 6.64 & & & \\
\hline Averages followed by the same capital letter on the line and lowercase in the column, do not differ by Scott Knott's test at 5\% \\
probability. CV: coefficient of variation. NNM: number of nodes at maturity.
\end{tabular}


According to Kantolic and Slafer (2007), the number of nodes is high when the light intensity is high, sowing in November, that plants are exposed to a longer period of light in their cycles, a fact that may be related to the higher NMR for sowing in october and november.

The interception of light by plants is extremely important for the development of reproductive buds, production and reserve of photoassimilates and reduction of abortion of flowers and pods (BOARD; HARVILLE, 1994).

It was observed that in the delay of the sowing season there was a decrease in the average of the NP (Table 7).

Table 7. Averages number of total pods evaluated in twelve soybean cultivars at four sowing seasons in the municipality of Uberlândia, MG, in the agricultural year of 2016/2017.

\begin{tabular}{lccccc}
\hline & \multicolumn{5}{c}{ NP } \\
\cline { 2 - 6 } CULTIVARS & \multicolumn{3}{c}{ SOWING SEASONS } \\
\cline { 2 - 6 } & $\mathbf{2 2 / 1 0 / 2 0 1 6}$ & $\mathbf{0 5 / 1 1 / 2 0 1 6}$ & $\mathbf{2 2 / 1 2 / 2 0 1 6}$ & $\mathbf{0 5 / 0 1 / 2 0 1 7}$ & Averages \\
\hline UFUS 6901 & $56.06 \mathrm{Ab}$ & $28.06 \mathrm{Bb}$ & $27.10 \mathrm{Bb}$ & $13.06 \mathrm{Ca}$ & 31.08 \\
UFUS 7415 & $66.30 \mathrm{Aa}$ & $54.90 \mathrm{Aa}$ & $17.55 \mathrm{Bc}$ & $7.45 \mathrm{Ba}$ & 36.55 \\
BRSMG 68 & $45.86 \mathrm{Ab}$ & $58.05 \mathrm{Aa}$ & $17.80 \mathrm{Bc}$ & $16.35 \mathrm{Ba}$ & 34.52 \\
TMG 801 & $42.85 \mathrm{Ab}$ & $28.95 \mathrm{Bb}$ & $26.25 \mathrm{Bb}$ & $13.75 \mathrm{Ca}$ & 27.95 \\
TMG 7062 IPRO & $74.05 \mathrm{Aa}$ & $28.11 \mathrm{Bb}$ & $16.10 \mathrm{Cc}$ & $9.50 \mathrm{Ca}$ & 31.94 \\
TMG 2158 IPRO & $70.93 \mathrm{Aa}$ & $28.30 \mathrm{Bb}$ & $16.30 \mathrm{Bc}$ & $6.15 \mathrm{Ca}$ & 30.42 \\
BRS 7270 IPRO & $44.80 \mathrm{Ab}$ & $38.25 \mathrm{Ab}$ & $8.73 \mathrm{Bc}$ & $7.85 \mathrm{Ba}$ & 24.91 \\
NA 5909 RR & $48.53 \mathrm{Ab}$ & $45.65 \mathrm{Aa}$ & $15.70 \mathrm{Bc}$ & $3.66 \mathrm{Ba}$ & 28.39 \\
NS 6909 RR & $69.65 \mathrm{Aa}$ & $53.86 \mathrm{Ba}$ & $14.46 \mathrm{Cc}$ & $5.50 \mathrm{Ca}$ & 35.87 \\
CD 2737 RR & $77.13 \mathrm{Aa}$ & $28.60 \mathrm{Bb}$ & $21.05 \mathrm{Bc}$ & $11.13 \mathrm{Ca}$ & 34.48 \\
P98Y30 RR & $70.93 \mathrm{Aa}$ & $44.75 \mathrm{Ba}$ & $39.50 \mathrm{Ba}$ & $10.05 \mathrm{Ca}$ \\
BMX Desafio RR & $55.05 \mathrm{Ab}$ & $28.60 \mathrm{Bb}$ & $23.55 \mathrm{Bb}$ & $16.40 \mathrm{Ba}$
\end{tabular}

Averages followed by the same capital letter on the line and lowercase in the column, do not differ by Scott Knott's test at $5 \%$ probability. CV: coefficient of variation. NP: number of total pods.

The reduction of the number of pods may have occurred due to the abortion of flowers and pods by several factors, such as the smaller reserve of photoassimilates available, the plants were subject to less light for interception, besides having smaller height, number of nodes, among other factors.

Meotti et al. (2012) evaluating sowing seasons and cultivars, observed a high correlation between productivity and number of pods and verified that, with the delay of sowing, the number of pods decreased for all cultivars, reflecting negatively on productivity.

With the sowing delay, an increase in the average number of tainted pods was observed (Table 8).

At the sowing of December, a greater number of pods were found, the plants presented more pods, however a great number were tainted. In late sowing the grain quality is affected, since the first crops harvested are sources of diseases and pests insects. Bedbugs disperse to later neighboring crops that are developing pods and grains, causing irreversible grain damage (HOFFMANN-CAMPO et al., 2000).

As the sowing delay occurred, all cultivars presented a reduction in productivity (Table 9). With the reduction of the photoperiod the plants presented lower height, lower vegetative canopy and, consequently, less photoassimilates production, which are responsible for the filling of grains, which compromised productivity. 
Table 8. Averages number of tainted pods evaluated in twelve soybean cultivars at four sowing seasons in the municipality of Uberlândia, MG, in the agricultural year of 2016/2017.

\begin{tabular}{|c|c|c|c|c|c|}
\hline \multirow{3}{*}{ CULTIVARS } & \multicolumn{5}{|c|}{ NTP } \\
\hline & \multicolumn{5}{|c|}{ SOWING SEASONS } \\
\hline & $22 / 10 / 2016$ & $05 / 11 / 2016$ & $22 / 12 / 2016$ & $05 / 01 / 2017$ & Averages \\
\hline UFUS 6901 & $0.10 \mathrm{Ba}$ & $0.65 \mathrm{Ba}$ & $8.00 \mathrm{Aa}$ & $2.40 \mathrm{Ba}$ & 2.79 \\
\hline UFUS 7415 & $0.30 \mathrm{Ba}$ & $0.50 \mathrm{Ba}$ & $9.30 \mathrm{Aa}$ & $1.35 \mathrm{Ba}$ & 2.86 \\
\hline BRSMG 68 & $0.15 \mathrm{Ba}$ & $1.20 \mathrm{Ba}$ & $10.45 \mathrm{Aa}$ & $1.15 \mathrm{Ba}$ & 3.24 \\
\hline TMG 801 & $1.60 \mathrm{Ba}$ & $1.75 \mathrm{Ba}$ & $7.15 \mathrm{Aa}$ & $3.50 \mathrm{Ba}$ & 3.50 \\
\hline TMG 7062 IPRO & $0.20 \mathrm{Ba}$ & $0.06 \mathrm{Ba}$ & $3.45 \mathrm{Ab}$ & $3.55 \mathrm{Aa}$ & 1.82 \\
\hline TMG 2158 IPRO & $0.25 \mathrm{Aa}$ & $0.20 \mathrm{Aa}$ & $2.65 \mathrm{Ab}$ & $1.85 \mathrm{Aa}$ & 1.24 \\
\hline BRS 7270 IPRO & $0.15 \mathrm{Ba}$ & $0.15 \mathrm{Ba}$ & $0.60 \mathrm{Bc}$ & $3.90 \mathrm{Aa}$ & 1.20 \\
\hline NA 5909 RR & $0.10 \mathrm{Aa}$ & $0.10 \mathrm{Aa}$ & $0.80 \mathrm{Ac}$ & $1.70 \mathrm{Aa}$ & 0.68 \\
\hline NS 6909 RR & $0.25 \mathrm{Aa}$ & $0.65 \mathrm{Aa}$ & $1.00 \mathrm{Ac}$ & $0.40 \mathrm{Aa}$ & 0.58 \\
\hline CD 2737 RR & $0.40 \mathrm{Ba}$ & $0.20 \mathrm{Ba}$ & $3.70 \mathrm{Ab}$ & $2.35 \mathrm{Aa}$ & 1.66 \\
\hline P98Y30 RR & $0.26 \mathrm{Ba}$ & $0.25 \mathrm{Ba}$ & $7.85 \mathrm{Aa}$ & $0.40 \mathrm{Ba}$ & 2.19 \\
\hline BMX Desafio RR & $0.05 \mathrm{Aa}$ & $0.40 \mathrm{Aa}$ & $3.45 \mathrm{Ab}$ & $0.95 \mathrm{Aa}$ & 1.21 \\
\hline Averages & 0.32 & 0.51 & 4.87 & 1.96 & \\
\hline CV $(\%)$ & 151.05 & & & & \\
\hline
\end{tabular}

Table 9. Averages Grain productivity $\left(\mathrm{kg} \mathrm{ha}^{-1}\right)$, evaluated in twelve soybean cultivars at four sowing seasons in the municipality of Uberlândia, MG, in the agricultural year of 2016/2017.

PROD

\begin{tabular}{lccccc} 
& \multicolumn{5}{c}{ SOWING SEASONS } \\
\cline { 2 - 6 } CULTIVARS & $\mathbf{2 2 / 1 0 / 2 0 1 6}$ & $\mathbf{0 5 / 1 1 / 2 0 1 6}$ & $\mathbf{2 2 / 1 2 / 2 0 1 6}$ & $\mathbf{0 5 / 0 1 / 2 0 1 7}$ & Averages \\
\hline UFUS 6901 & $4383.31 \mathrm{Ad}$ & $4138.58 \mathrm{Aa}$ & $1481.06 \mathrm{Bb}$ & $437.93 \mathrm{Cb}$ & 2610.22 \\
UFUS 7415 & $5433.22 \mathrm{Ab}$ & $3599.57 \mathrm{Bb}$ & $1106.67 \mathrm{Cb}$ & $575.37 \mathrm{Db}$ & 2678.71 \\
BRSMG 68 & $3963.13 \mathrm{Ad}$ & $4051.06 \mathrm{Aa}$ & $1801.52 \mathrm{Ba}$ & $930.04 \mathrm{Ca}$ & 2686.44 \\
TMG 801 & $3998.26 \mathrm{Ad}$ & $2756.39 \mathrm{Bc}$ & $2030.11 \mathrm{Ca}$ & $1076.00 \mathrm{Da}$ & 2465.19 \\
TMG 7062 IPRO & $6100.00 \mathrm{Aa}$ & $3922.17 \mathrm{Ba}$ & $1479.19 \mathrm{Cb}$ & $925.89 \mathrm{Da}$ & 3106.82 \\
TMG 2158 IPRO & $4856.16 \mathrm{Ac}$ & $3202.58 \mathrm{Bc}$ & $1420.53 \mathrm{Cb}$ & $393.36 \mathrm{Db}$ & 2468.16 \\
BRS 7270 IPRO & $4910.26 \mathrm{Ac}$ & $3544.04 \mathrm{Bb}$ & $1093.74 \mathrm{Cb}$ & $320.09 \mathrm{Db}$ & 2467.04 \\
NS 5909 RR & $5369.28 \mathrm{Ab}$ & $3523.12 \mathrm{Bb}$ & $1119.09 \mathrm{Cb}$ & $274.67 \mathrm{Db}$ & 2571.54 \\
NS 6909 RR & $5813.18 \mathrm{Aa}$ & $3517.64 \mathrm{Bb}$ & $1372.62 \mathrm{Cb}$ & $407.82 \mathrm{Db}$ & 2777.82 \\
CD 2737 RR & $5100.16 \mathrm{Ab}$ & $3703.09 \mathrm{Bb}$ & $1538.81 \mathrm{Cb}$ & $471.55 \mathrm{Db}$ & 2703.41 \\
P98Y30 RR & $5869.67 \mathrm{Aa}$ & $3634.83 \mathrm{Bb}$ & $2136.56 \mathrm{Ca}$ & $560.40 \mathrm{Db}$ & 3050.37 \\
BMX Desafio RR & $5950.00 \mathrm{Aa}$ & $3269.26 \mathrm{Bc}$ & $1361.66 \mathrm{Cb}$ & $514.47 \mathrm{Db}$ & 2773.85 \\
\hline Averages & 5145.56 & 3571.86 & 1495.13 & 573.97 & \\
CV (\%) & 16.62 & & & \\
\hline Averages followed by the same capital letter on the line and lowercase in the column, do not differ by Scott Knott's test at 5\% \\
probability. CV: coefficient of variation. PROD: Grain productivity (kg ha ${ }^{-1}$ ).
\end{tabular}


There may be a $30-50 \%$ reduction in grain productivity in late sowing, and sowing in the offseason may cause losses of up to $70 \%$ compared to the recommended time (RODRIGUES et al., 2008). Therefore, the adoption of sowing times that allow climatic conditions close to those required by the plants is important to express the productive potential in soybean cultivation (PEIXOTO et al., 2000).

Another factor of extreme importance in the reduction of productivity was the decrease of the precipitation during the month of February, period of grain filling of the last two sowing seasons, which also favored plants with lower HPM and NNM, with delay of sowing. The vegetative and reproductive cycle of the plants were not reduced gradually with delay of the sowing season in this work, however, the decrease of the photoperiod as the sowing delay and reduction of the precipitation in the period of grain filling of the last two seasons, reduced HPM, NNM and consequently productivity (Table 9).

Changes in plant morphology and architecture may influence grain productivity
(FARIAS; NEPOMUCENO; NEUMAIER, 1993), according to the present work, occurring alteration in plant height and number of nodes as sowing is delayed. Thus, the sowing time acts decisively on the quality and quantity of the production (MOTTA et al., 2000).

Amorim et al. (2011), Meotti et al. (2012) and Balena et al. (2016), as well as the present study, observed a reduction in grain productivity with sowing delay.

\section{CONCLUSIONS}

The sowing times that contributed to obtain favorable agronomic traits and high productivity were October and November. Sowing delay seriously affected soybean yield and in the Uberlândia MG region the ideal sowing time was October 22, before the beginning of November.

Considering the late sowing in December and January, the cultivars that had their productivities less affected in these two seasons were the conventional cultivars BRSMG 68 and TMG 801.

RESUMO: A soja apresenta grande expressão econômica e alto impacto no agronegócio brasileiro. O potencial produtivo de uma cultivar é expresso de acordo com a constituição genética e o ambiente. A época de semeadura exerce influência sobre os caracteres agronômicos da soja, impactando no rendimento de grãos. $\mathrm{O}$ objetivo deste estudo, avaliar a influência da época de semeadura sobre o potencial produtivo e caracteres agronômicos de soja. $\mathrm{O}$ trabalho foi conduzido na Fazenda experimental Capim Branco, pertencente à Universidade Federal de Uberlândia. Foram utilizadas 12 cultivares (UFUS 6901, UFUS 7415, BRSMG 68, TMG 801, TMG 7062 IPRO, TMG 2158 IPRO, BRS 7270 IPRO, NA 5909 RR, NS 6909 RR, CD 2737 RR, P98Y30 RR e BRASMAX Desafio RR) e quatro épocas de semeadura (22 de outubro, 05 de novembro, 22 de dezembro de 2016 e 05 de janeiro de 2017). Adotou-se o delineamento experimental de blocos casualizados com quatro repetições. Os caracteres avaliados foram: número de dias para o florescimento e maturidade, altura da planta na maturidade, número de nós na maturidade, altura de inserção da primeira vagem, número total de vagens, número de vagens chochas e produtividade. As semeaduras realizadas em outubro e novembro contribuíram para a obtenção de maior número de nós e maior altura de plantas na maturidade, que são caracteres agronômicos favoráveis à maiores produtividades. $\mathrm{O}$ atraso na semeadura afetou seriamente a produção de soja na região de Uberlândia $M G$ e a época de semeadura ideal foi em 22 de outubro, antes do início de novembro. Nas semeaduras tardias dezembro e janeiro, as cultivares que tiveram suas produtividades menos afetadas foram as cultivares convencionais BRSMG 68 e TMG 801.

PALAVRA-CHAVE: Glycine max. Manejo cultural. Previsibilidade.

\section{REFERENCES}

AMORIN, F. A.; KAMAWAKI, O. T.; SOUSA, L. B.; LANA, R. M. Q.; HAMAWAKI, C. D. L. Época de semeadura no potencial produtivo de soja em Uberlândia, MG. Semina: Ciências Agrárias, Londrina v. 32, n. 1, p. 1793-1802, 2011. https://doi.org/10.5433/1679-0359.2011v32Suplp1793

BALENA, R.; GIACOMINI, C. T.; BENDER, A. C.; NESI, C. N. Época de semeadura e espaçamentos entre linhas na produtividade da soja. Unoesc \& Ciência-ACBS, Joaçaba, v. 7, n. 1, p. 61-68, 2016. 
BOARD, J. E.; HARVILLE, B. G.; A criterion for acceptance of narrow-row culture in soybean. Agronomy Journal, Madison, v. 86, n. 6, p. 1103-1106, November-December, 1994. https://doi.org/10.2134/agronj1994.00021962008600060033x

CÂMARA, G. M. de S.; HEIFFIG, L. S. Fisiologia, ambiente e rendimento da cultura da soja. In: CÂMARA.; G. M. S. (Ed.). Tecnologia da produção II. Piracicaba: Esalq/USP, 2000. 120 p.

CRUZ, C. D. Genes Software - extended and integrated with the R, Matlab and Selegen. Acta Scientiarum. Agronomy, v. 38, n. 4, p. 547-552, 2016. ttps://doi.org/10.4025/actasciagron.v38i3.32629

CRUZ, T. V.; PEIXOTO, C. P.; MARTINS, M. C.; PINTO, M. D. F. S. Componentes de produção de soja em diferentes épocas de semeadura no oeste da Bahia. Bioscience Journal, v. 26, n. 5, p. 709-716, 2010.

EMPRESA BRASILEIRA DE PESQUISA AGROPECUÁRIA - EMBRAPA. Tecnologias de produção de soja - região central do Brasil 2012 e 2013. Londrina: Embrapa Soja, 2011. 261 p. EMPRESA BRASILEIRA DE PESQUISA AGROPECUÁRIA - EMBRAPA. Tecnologias de produção de soja - região central do Brasil 2014. Londrina: Embrapa Soja, 2013. 266 p.

FARIAS, J. R. B.; NEPOMUCEMO, A. L.; NEUMAIER, N. Rendimento de genótipos semiprecoces de soja submetidos ou não a irrigação. Revista Brasileira de Fisiologia Vegetal, São Carlos, v. 5, n. 1, p. 57 , 1993.

FARIAS, J. R. B.; NEPOMUCEMO, A. L.; NEUMAIER, N. Ecofisiologia da soja. Londrina: Embrapa Soja Circular Técnica, 2007. 10 p.

FEHR, W. R.; CAVINESS, C. E. Stages of soybean development. Ames: Iowa State University of Science and Technology, 1977. $11 \mathrm{p}$.

GUIMARÃES, F. S.; REZENDE, P. M.; CASTRO, E. M.; CARVALHO, E. A.; ANDRADE, M. J. B.; CARVALHO, E. R. Cultivares de soja [Glycine max (L.) Merrill] para cultivo de verão na região de LavrasMG. Ciência e Agrotecnologia, v. 32, n. 4, p. 1099-1106, 2008. https://doi.org/10.1590/S141370542008000400010

HOFFMANN-CAMPO, C. B.; MOSCARDI, F.; CORRÊA-FERREIRA, B. S.; OLIVEIRA, L. J.; SOSAGÓMEZ, D. R.; PANIZZI, A. R.; OLIVEIRA, E. B. Pragas da soja no Brasil e seu manejo integrado. Londrina: Embrapa soja - Circular Técnica, 2000. 70 p.

KANTOLIC, A. G.; SLAFER, G. A.; Development and seed number in indeterminate soybean as affected by timing and duration of exposure to long photoperiods after flowering. Annals of botany, v. 99, n. 5, p. 925933, 2007. https://doi.org/10.1093/aob/mcm033

KÖPPEN, W. Climatologia: com um estúdio de los climas de la tierra. México: Fondo de Cultura Economica, 1948. 478 p.

KUMAGAI, E.; SAMESHIMA, R. Genotypic differences in soybean yield responses to increasing temperature in a cool climate are related to maturity group. Agricultural and forest meteorology, v. 198, p. $265-272,2014$. https://doi.org/10.1016/j.agrformet.2014.08.016

LUDWIG, M. P.; DUTRA, L. M. C; LUCCA FILHO, O. A.; ZABOT, L.; UHRY, D.; LISBOA, J. I.; JAUER, A. Características morfológicas de cultivares de soja convencionais e Roundup ReadyTM em função da época e densidade de semeadura. Ciência Rural, v. 40, p. 759-767, 2010. https://doi.org/10.1590/S010384782010000400003

MEOTTI, G. V.; BENIN, G.; SILVA, R. R.; BECHE, E.; MUNARO, L. B. Épocas de semeadura e desempenho agronômico de cultivares de soja. Pesquisa Agropecuária Brasileira, Brasília, DF, v. 47, n. 1, p. 14-21, 2012. https://doi.org/10.1590/S0100-204X2012000100003 
MOTTA, I. S.; BRACCINI, A. L.; SCAPIM, C. A.; GONÇALVES, A. C. A.; BRACCINI, M. C. L. Características agronômicas e componentes da produção de sementes de soja em diferentes épocas de semeadura. Revista brasileira de sementes, v. 22, n. 2, p. 153-162, 2000. https://doi.org/10.17801/01013122/rbs.v22n2p153-162

NOGUEIRA, A. P. O.; SEDIYAMA, T.; DE SOUSA, L. B.; HAMAWAKI, O. T.; CRUZ, C. D.; PEREIRA, D. G.; MATSUO, E. Análise de trilha e correlações entre caracteres em soja cultivada em duas épocas de semeadura. Bioscience Journal, Uberlândia, v. 28, n. 6, p. 877-888, 2012.

NOGUEIRA, A. P. O.; SEDIYAMA, T.; OLIVEIRA, R. C. T.; DESTRO, D. Estádios de desenvolvimento. In: SEDIYAMA (Ed.). Tecnologias de produção de sementes de soja. Londrina, PR: Mecenas. 2013. p. 15-44.

PEIXOTO, C. P.; CÂMARA, G. M. de S.; MARTINS, M. C.; MARCHIORI, L. F. S.; GUERZONI, R. A.; MATTIAZZI, P. Épocas de semeadura e densidade de plantas de soja: componentes da produção e rendimento de grãos. Scientia Agrícola, v. 57, p. 47-61, 2000. https://doi.org/10.1590/S0103-90162000000100015

RAMALHO, M. A. P.; ABREU, A. F. B.; SANTOS, J. B. dos; NUNES, J. A. R. Aplicações da genética quantitativa no melhoramento de plantas autógamas. Lavras: Editora UFLA, 2012, 522 p.

RODRIGUES, O.; TEIXEIRA, M. C. C.; COSTENARO, E. R.; AVOZANI, A. Rendimento de grãos de soja em semeadura tardia. Passo Fundo: Embrapa Trigo, 2008. 26p. (Embrapa Trigo. Boletim de pesquisa e desenvolvimento online, 66).

SEDIYAMA, T. Tecnologias de produção e usos da soja. Londrina: Mecenas, 2009. 314 p.

SEDIYAMA, T.; MATSUO, E.; OLIVEIRA, R. C. T.; GLASENAPP, J. S. Características agronômicas de cultivares. In: SEDIYAMA, T. (Ed.) Melhoramento genético da soja. Londrina: Mecenas, 2015. 352 p.

SEDIYAMA, T.; TEIXEIRA, R. de C.; BARROS, H. B. Origem, evolução e importância econômica. In: SEDIYAMA, T. (Ed.). Tecnologias de produção e usos da soja. Londrina: Mecenas, 2009. 1-5 p.

SILVA, A. F.; SEDIYAMA, T.; BORÉM, A. Exigências edafoclimáticas. In: SEDIYAMA, T.; SILVA, F.; BORÉM, A.; (Eds). Soja do plantio à colheita. Viçosa: UFV, 2015. 54-65 p. 